Correspondence

An Coorevits

An.Coorevits@HoGent.be

\section{Bacillus thermolactis sp. nov., isolated from dairy farms, and emended description of Bacillus thermoamylovorans}

\author{
An Coorevits, ${ }^{1,2}$ Niall A. Logan, ${ }^{3}$ Anna E. Dinsdale, ${ }^{4}$ Gillian Halket, ${ }^{3}$ \\ Patsy Scheldeman, ${ }^{5}$ Marc Heyndrickx, ${ }^{5}$ Peter Schumann, ${ }^{6}$ \\ Anita Van Landschoot ${ }^{1,2}$ and Paul De Vos ${ }^{2}$ \\ ${ }^{1}$ Laboratory of Biochemistry and Brewing, Faculty of Applied Engineering Sciences, University \\ College Ghent, Schoonmeerstraat 52, 9000 Ghent, Belgium \\ ${ }^{2}$ Laboratory of Microbiology (LM-UGent), Department of Biochemistry and Microbiology, Ghent \\ University, K.L. Ledeganckstraat 35, 9000 Ghent, Belgium \\ ${ }^{3}$ Department of Biological and Biomedical Sciences, Glasgow Caledonian University, Cowcaddens \\ Road, Glasgow G4 OBA, UK \\ ${ }^{4}$ Campden BRI, Chipping Campden, Gloucestershire GL55 6LD, UK \\ ${ }^{5}$ Institute for Agricultural and Fisheries Research, Technology and Food Unit, Food Safety, \\ Brusselsesteenweg 370, 9090 Melle, Belgium \\ ${ }^{6}$ DSMZ German Collection of Microorganisms and Cell Cultures, Inhoffenstr. 7B, D-38124 \\ Braunschweig, Germany
}

A polyphasic taxonomic study was performed on 22 thermotolerant, aerobic, endospore-forming bacteria from dairy environments. Seventeen isolates were retrieved from raw milk, one from a filter cloth and four from grass, straw or milking equipment. These latter four isolates (R-6546, R-7499, R-7764 and R-7440) were identified as Bacillus thermoamylovorans based on DNA-DNA hybridizations (values above $70 \%$ with Bacillus thermoamylovorans LMG $18084^{\top}$ ) but showed discrepancies in characteristics with the original species description, so an emended description of this species is given. According to $16 \mathrm{~S}$ rRNA gene sequence analysis and DNA-DNA hybridization experiments, the remaining 18 isolates $\left(R-6488^{\top}, R-28193, R-6491, R-6492\right.$, R-7336, R-33367, R-6486, R-6770, R-31288, R-28160, R-26358, R-7632, R-26955, $\mathrm{R}-26950, \mathrm{R}-33520, \mathrm{R}-6484, \mathrm{R}-26954$ and R-7165) represented one single species, most closely related to Bacillus thermoamylovorans (93.9\% 16S rRNA gene sequence similarity), for which the name Bacillus thermolactis is proposed. Cells were Gram-stain-positive, facultatively anaerobic, endospore-forming rods that grew optimally at $40-50{ }^{\circ} \mathrm{C}$. The cell wall peptidoglycan type of strain R-6488 ${ }^{\top}$, the proposed type strain, was $A 1 \gamma$ based on meso-diaminopimelic acid. Major fatty acids of the strains were $\mathrm{C}_{16: 0}(28.0 \%)$, iso- $\mathrm{C}_{16: 0}(12.1 \%)$ and iso- $\mathrm{C}_{15: 0}(12.0 \%)$. MK-7 was the predominant menaquinone, and major polar lipids were diphosphatidylglycerol, phosphatidylglycerol and some unidentified phospholipids. DNA G + C content was 35.0 mol\%. Phenotypic properties allowed discrimination from other thermotolerant species of the genus Bacillus and supported the description of the novel species Bacillus thermolactis, with strain R-

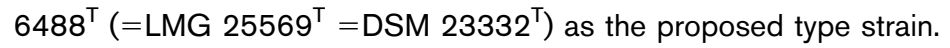

The GenBank/EMBL/DDBJ accession numbers for the 16S rRNA gene sequences of strains R-6484, R-6486, R-6488'T, R-7165, R-6491, R-6492, R6770, R-7336, R-7632, R-33520, R-28193, R-31288, R-26955, R-26358, R-33367, R-26954, R-26950, R-28160, R-7499, R-6546, R-7764 and R7440 are FN666256, FN997657, AY397764, FN997658, FN666257, FN997656, FN997655, FN997659, FN997654, AM910339, AM910224, AM910312, AM910187, FN997653, AM910336, AM910186, AM910183, AM910223, AY373320, FN666258, FN666260 and FN666259, respectively.

Five supplementary figures are available with the online version of this paper. 
The genus Bacillus grew historically as a dumping ground for all Gram-positive, aerobic, spore-forming, rod-shaped bacteria, resulting in a very heterogeneous genus comprising metabolically diverse species. This heterogeneity made it difficult to recognize general characteristics for the genus. Since the use of molecular techniques in the early 1990s, several efforts have been made to elucidate the phylogeny of members within the genus Bacillus, resulting in a more reliable taxonomy, including the creation of new genera of spore-forming bacteria such as Paenibacillus (Ash et al., 1994), Brevibacillus, Aneurinibacillus (Shida et al., 1996), Virgibacillus (Heyndrickx et al., 1998), Geobacillus (Nazina et al., 2001) and Ureibacillus (Fortina et al., 2001). Still, at the time of writing, the taxonomy of the genus is constantly evolving, with the accommodation of novel species and the transfer of described species into new or already described genera.

Owing to their endospores, members of the genus Bacillus are able to persist in various environments, including foodstuffs, where they often pose contamination and spoilage problems. The dairy industry, for instance, is a field frequently associated with spore-forming contaminants. Bacteria contaminate the milk during the primary production stage (the milking process), and cannot be eliminated during further processing as their spores survive the decontamination steps applied (pasteurization or Ultra Heat Treatment) (Pettersson et al., 1996). These endospore-formers affect milk quality and safety through production of proteolytic and/or lipolytic enzymes that cause off-flavours and structural defects of the milk, and by the potential production of toxins associated with foodborne illnesses (Meer et al., 1991; Crielly et al., 1994; Andersson et al., 1995).

Two previous studies (Scheldeman et al., 2005; Coorevits et al., 2008) focusing on the diversity of (highly) heat resistant endospore-forming bacteria in milk from Belgian dairy farms collected 22 isolates that could not unequivocally be identified to the species level. On the basis of partial $16 \mathrm{~S}$ rRNA gene sequencing, these isolates appeared to represent Bacillus thermoamylovorans, and a novel species of the genus Bacillus. Bacillus thermoamylovorans was first isolated in 1995 from a palm wine sample in Senegal (Combet-Blanc et al., 1995). It was described as a non-spore-forming, moderately thermophilic, facultatively anaerobic, Gram-positive rod. Following further characterization of the isolates using a polyphasic taxonomic approach as recommended by Logan et al. (2009), an emended description of Bacillus thermoamylovorans (Combet-Blanc et al., 1995) is given as discrepancies with the original species description were observed, and the species Bacillus thermolactis sp. nov. is proposed.

All twenty-two isolates originated from dairy farm environments, more specifically from raw milk samples, straw, grass, milking equipment and a filter cloth, and were retrieved during a summer and a winter isolation campaign at Belgian dairy farms. Samples obtained during the first study (Scheldeman et al., 2005) were heat-treated (30 min at $100{ }^{\circ} \mathrm{C}$ ) to select for highly heat-resistant spore-formers specifically, while samples obtained during the later study (Coorevits et al., 2008) were heat treated $\left(10 \mathrm{~min}\right.$ at $80^{\circ} \mathrm{C}$ ) to select for all spore-formers. Samples were incubated at $55{ }^{\circ} \mathrm{C}$ for $24 \mathrm{~h}$ to select for thermotolerant spore-formers. All isolates were further subcultured on Brain Heart Infusion Agar (BHI, Oxoid), supplemented with vitamin $\mathrm{B}_{12}\left(1 \mathrm{mg} \mathrm{ml}{ }^{-1}\right)$ at $55{ }^{\circ} \mathrm{C}$. The isolates, their sources and isolation conditions are listed in Table 1.

Total genomic DNA for 16S rRNA gene sequencing and DNA fingerprinting was extracted as described by Coorevits et al. (2008). The nearly complete $16 \mathrm{~S}$ rRNA gene sequences of all isolates were generated as described by Heyrman \& Swings (2001). Sequencing products were purified with a Big Dye XTerminator Purification kit (Applied Biosystems) according to the manufacturer's instructions using sequential pipetting and a MixMate (Eppendorf) shaking device. Sequences were assembled using the BioNumerics 5.1 software (Applied Maths, Belgium) and the 50 most closely related organisms were appraised using the online FASTA tool of EMBL (http:// www.ebi.ac.uk/Tools/sss/fasta/). FASTA results indicated that these isolates were members of the genus Bacillus. A phylogenetic tree harbouring all species of the genus Bacillus with validly described names at the time of writing confirmed the position of strain $\mathrm{R}-6488^{\mathrm{T}}$ within this genus, with Bacillus thermoamylovorans as its closest relative (Supplementary Figure S1, available in IJSEM online). A detailed view of part of this tree, with all isolates and their closest relatives included, is represented in Fig. 1. Both phylogenetic trees were based on almost complete $16 \mathrm{~S}$ rRNA gene sequences and were reconstructed by aligning all sequences using CLUSTAL X (Thompson et al., 1997) and trimming the overhangs. The jModelTest 0.1.1 program (Posada, 2008) was then applied to the datasets to determine the best-fit evolutionary model. Maximumlikelihood analyses were performed using PhyML (Guindon \& Gascuel, 2003) by applying the parameters determined by jModelTest. Approximate likelihood ratio test values were calculated to assess the reliability of the clusters (Anisimova \& Gascuel, 2006). Additional maximum-parsimony and neighbour-joining analyses were performed using MEGA4 (Tamura et al., 2007) for the tree represented in Fig. 1. Resulting phylogenetic trees are shown in Supplementary Figures S2 and S3, respectively, and support the maximum-likelihood analysis. One group of milk isolates (strains R-33520, R-6488 ${ }^{\mathrm{T}}$, R-6770, R-6491, R-7336， R-31288， R-7632，R-7165，R-28193， R-6492, R-6484，R-33367，R-26954，R-26950，R-26955，R-6486, R-26358 and R-28160) showed less than $0.7 \%$ variability in $16 \mathrm{~S}$ rRNA gene sequences with each other and with two Bacillus sp. strains, TAT105 and TAT112, representing two patented micro-organisms. The closest relative to this group of strains was Bacillus thermoamylovorans LMG $18084^{\mathrm{T}}$, sharing $93.9 \% 16 \mathrm{~S}$ rRNA gene sequence similarity with strain $\mathrm{R}-6488^{\mathrm{T}}$. These values indicated that the 
Table 1. Overview of all isolates and their corresponding isolation conditions

For all isolates, the isolation location is Flanders, the isolation medium is $\mathrm{BHI}+\operatorname{vitamin} \mathrm{B}_{12}$.

\begin{tabular}{|c|c|c|c|c|}
\hline \multirow[t]{2}{*}{ Strain } & \multicolumn{3}{|c|}{ Isolation parameters } & \multirow[t]{2}{*}{ Study } \\
\hline & Source & Period & Heat treatment & \\
\hline \multicolumn{5}{|l|}{ Bacillus thermolactis sp. nov. } \\
\hline $\mathrm{R}-6484$ & Filter cloth & Winter & $30 \min , 100{ }^{\circ} \mathrm{C}$ & Scheldeman et al. (2005) \\
\hline R-6486 & Raw milk & Winter & $30 \mathrm{~min}, 100{ }^{\circ} \mathrm{C}$ & Scheldeman et al. (2005) \\
\hline R-6488 ${ }^{\mathrm{T}}\left(=\mathrm{LMG} 25569^{\mathrm{T}} ;=\right.$ DSM $\left.23332^{\mathrm{T}}\right)$ & Raw milk & Winter & $30 \mathrm{~min}, 100{ }^{\circ} \mathrm{C}$ & Scheldeman et al. (2005) \\
\hline $\mathrm{R}-7165$ & Raw milk & Winter & $30 \mathrm{~min}, 100{ }^{\circ} \mathrm{C}$ & Scheldeman et al. (2005) \\
\hline R-6491 & Raw milk & Winter & $30 \mathrm{~min}, 100{ }^{\circ} \mathrm{C}$ & Scheldeman et al. (2005) \\
\hline R-6492 & Raw milk & Winter & $30 \mathrm{~min}, 100{ }^{\circ} \mathrm{C}$ & Scheldeman et al. (2005) \\
\hline R-6770 & Raw milk & Winter & $30 \mathrm{~min}, 100{ }^{\circ} \mathrm{C}$ & Scheldeman et al. (2005) \\
\hline R-7336 & Raw milk & Winter & $30 \mathrm{~min}, 100{ }^{\circ} \mathrm{C}$ & Scheldeman et al. (2005) \\
\hline R-7632 & Raw milk & Winter & $30 \mathrm{~min}, 100{ }^{\circ} \mathrm{C}$ & Scheldeman et al. (2005) \\
\hline R-33520 & Raw milk & Winter & $10 \mathrm{~min}, 80^{\circ} \mathrm{C}$ & Coorevits et al. (2008) \\
\hline $\mathrm{R}-28193$ & Raw milk & Summer & $10 \mathrm{~min}, 80^{\circ} \mathrm{C}$ & Coorevits et al. (2008) \\
\hline R-31288 & Raw milk & Winter & $10 \mathrm{~min}, 80^{\circ} \mathrm{C}$ & Coorevits et al. (2008) \\
\hline R-26955 & Raw milk & Summer & $10 \mathrm{~min}, 80^{\circ} \mathrm{C}$ & Coorevits et al. (2008) \\
\hline R-33378 & Raw milk & Winter & $10 \mathrm{~min}, 80^{\circ} \mathrm{C}$ & Coorevits et al. (2008) \\
\hline R-26358 & Raw milk & Summer & $10 \mathrm{~min}, 80^{\circ} \mathrm{C}$ & Coorevits et al. (2008) \\
\hline $\mathrm{R}-33367$ & Raw milk & Winter & $10 \mathrm{~min}, 80^{\circ} \mathrm{C}$ & Coorevits et al. (2008) \\
\hline $\mathrm{R}-26954$ & Raw milk & Summer & $10 \mathrm{~min}, 80^{\circ} \mathrm{C}$ & Coorevits et al. (2008) \\
\hline $\mathrm{R}-26950$ & Raw milk & Summer & $10 \min , 80^{\circ} \mathrm{C}$ & Coorevits et al. (2008) \\
\hline $\mathrm{R}-28160$ & Raw milk & Summer & $10 \min , 80^{\circ} \mathrm{C}$ & Coorevits et al. (2008) \\
\hline \multicolumn{5}{|l|}{ Bacillus thermoamylovorans } \\
\hline $\mathrm{R}-7499$ & Straw & Winter & $30 \mathrm{~min}, 100{ }^{\circ} \mathrm{C}$ & Scheldeman et al. (2005) \\
\hline R-6546 & Grass & Winter & $30 \mathrm{~min}, 100{ }^{\circ} \mathrm{C}$ & Scheldeman et al. (2005) \\
\hline R-7764 & Milking equipment & Winter & $30 \mathrm{~min}, 100{ }^{\circ} \mathrm{C}$ & Scheldeman et al. (2005) \\
\hline $\mathrm{R}-7440$ & Milking equipment & Winter & $30 \mathrm{~min}, 100{ }^{\circ} \mathrm{C}$ & Scheldeman et al. (2005) \\
\hline
\end{tabular}

above-mentioned isolates probably represented a novel species within the genus Bacillus. 16S rRNA gene sequences of strains R-7499, R-7440, R-6546 and R-7764 showed at least $99.2 \%$ similarity with each other and with the type strain of Bacillus thermoamylovorans (LMG $18084^{\mathrm{T}}$ ), indicating that these isolates probably belonged to this species. Surprisingly, two strains, WSBC20060 and WSBC20059 assigned to Bacillus circulans, also clustered in the vicinity of the Bacillus thermoamylovorans group. However, no further information could be found about these strains, and it was assumed these strains were probably wrongly identified and most likely should be allocated to Bacillus thermoamylovorans.

As prescribed by the minimal standards for describing new taxa of aerobic, endospore-forming bacteria (Logan et al., 2009), a fingerprint pattern of all isolates was generated using a repetitive sequence-based PCR with a $(\mathrm{GTG})_{5^{-}}$ primer (Heyrman et al., 2005). This allowed grouping of the isolates into manageable clusters of similar strains as described previously by Heyrman et al. (2004). Five unique fingerprint patterns could be distinguished, as shown in Supplementary Figure S4, and were assigned groups A-E (supported by a $90 \%$ cut-off value). For each group, representative strains were chosen for DNA-DNA hybridization experiments, namely strains R-33367, R-7499,
R-7440, R-6488 ${ }^{\mathrm{T}}$ and R-6484 (indicated in bold in Supplementary Figure S4). Indeed, it is generally recommended and accepted that strains with a DNA-DNA relatedness value below $70 \%$, or with $16 \mathrm{~S}$ rRNA gene sequence dissimilarity above $3 \%$, are considered as belonging to separate species. Yet, bacterial strains with a difference in $16 \mathrm{~S}$ rRNA gene sequence of less than $3 \%$ cannot be allocated to the same species without support from DNA-DNA hybridization experiments (Stackebrandt \& Ebers, 2006). For this purpose, approximately $1 \mathrm{~g}$ biomass from the representative strains, as well as from the type strain LMG $18084^{\mathrm{T}}$ of Bacillus thermoamylovorans, was harvested from tryptone soy agar (TSA; Oxoid) plates, and DNA was purified as described by Logan et al. (2000). DNA-DNA hybridization was performed using a modification of the microplate method of Ezaki et al. (1989) as described by Willems et al. (2001). A hybridization temperature of $32{ }^{\circ} \mathrm{C}$ (calculated with correction for the presence of $50 \%$ formamide) was used. DNA-DNA relatedness results confirmed $16 \mathrm{~S}$ rRNA gene sequence analyses, with strains R-6488 ${ }^{\mathrm{T}}$, R-6484 and R-33367 representing a novel species and strains R-7499 and R7440 belonging to Bacillus thermoamylovorans. An overview of DNA-DNA relatedness values between the strains is given in Table 2. DNA G $+\mathrm{C}$ contents of strains $\mathrm{R}-6488^{\mathrm{T}}$ and LMG $18084^{\mathrm{T}}$ were $35.0 \mathrm{~mol} \%$ and $37.0 \mathrm{~mol} \%$, 


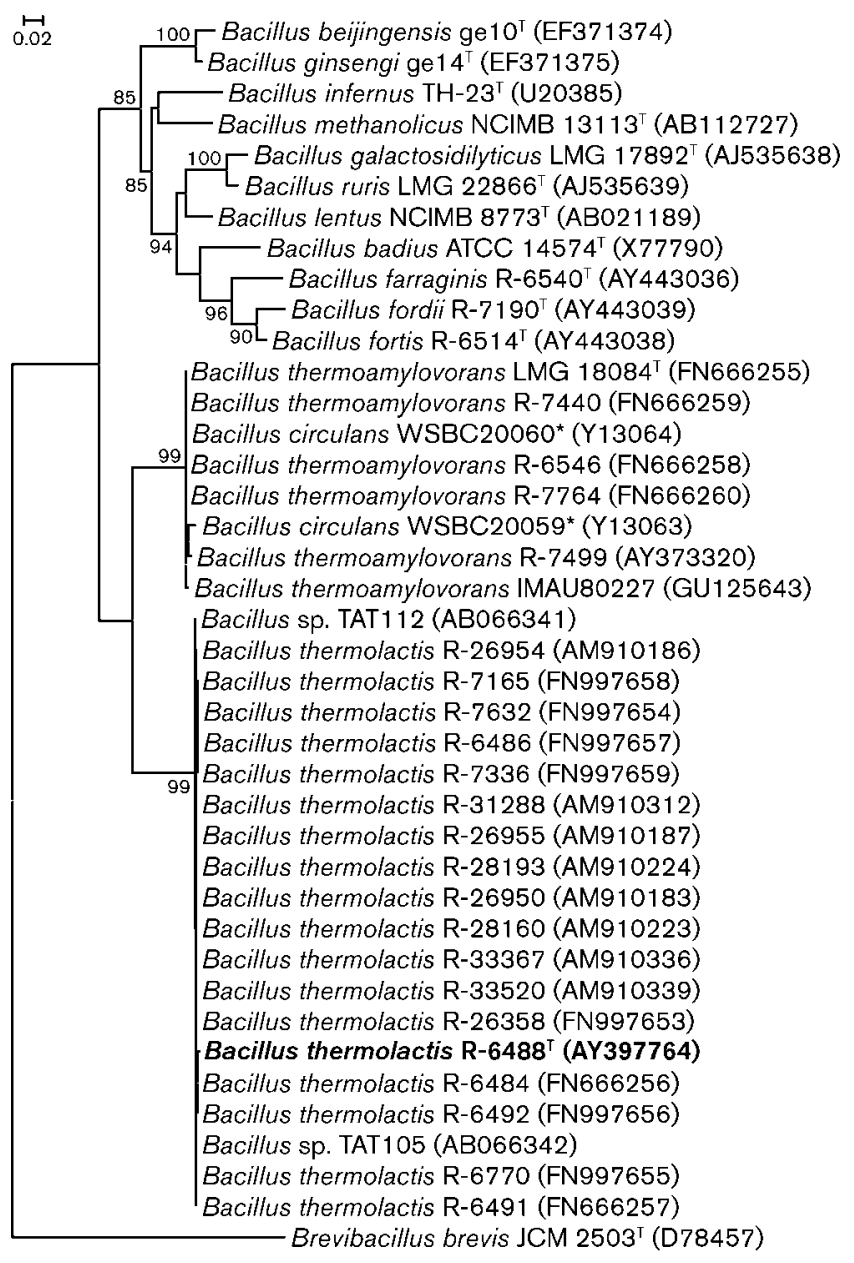

Fig. 1. Maximum-likelihood phylogenetic tree of the milk isolates with their closest relatives based on almost complete 16S rRNA gene sequences (1486 characters). Approximate likelihood ratio test values (at least $85 \%$ ) are shown at branch points. Sequence accession numbers are in parentheses. The 16S rRNA gene sequence of Brevibacillus brevis JCM $2503^{\top}$ (D78457) was used as an outgroup to root the tree. The Bacillus thermolactis sp. nov. type strain, $\mathrm{R}-6488^{\top}$, is indicated in bold. *, these strains were probably wrongly identified and should be allocated to Bacillus thermoamylovorans. Bar, 0.02 substitutions per nucleotide position. respectively, as determined by HPLC (Mesbah et al., 1989), using further specifications given by Logan et al. (2000).

For phenotypic analysis, type strains of thermotolerant species were also included as follows: Bacillus thermoamylovorans LMG $18084^{\mathrm{T}}$, Bacillus fumarioli LMG $17489^{\mathrm{T}}$, Bacillus circulans LMG $13261^{\mathrm{T}}$, Bacillus coagulans LMG $6326^{\mathrm{T}}$ and Bacillus smithii LMG $12526^{\mathrm{T}}$. Bacillus fumarioli LMG $17489^{\mathrm{T}}$ was grown on Bacillus fumarioli agar (BFA) at pH 5.5 and $50{ }^{\circ} \mathrm{C}$ as described by Logan et al. (2000); all other strains were grown on TSA for $24 \mathrm{~h}$ at $50{ }^{\circ} \mathrm{C}$. Cellular morphology and motility were investigated by phasecontrast microscopy at $\times 1000$ magnification, and cells were Gram stained. Sporangial morphologies were studied in cultures grown for several days at $50{ }^{\circ} \mathrm{C}$ on TSA containing $5 \mathrm{mg} \mathrm{MnSO} \mathrm{ml}^{-1}$. Temperature, $\mathrm{pH}$ and salt tolerance ranges for growth were determined using the methods given by Logan \& De Vos (2009). Bacillus fumarioli $\mathrm{LMG} 17489^{\mathrm{T}}$ was characterized using API $20 \mathrm{E}$ and API 50 CHB kits (BioMérieux) at pH 6 as described by Logan et al. (2000); biochemical characteristics for other strains were tested using API 20E and API 50 CHB kits, according to the manufacturer's instructions but with incubation at $50{ }^{\circ} \mathrm{C}$. Kits were incubated within loosely closed plastic bags in order to maintain humidity. Characteristics differentiating between the species are shown in Table 3.

Whole cell hydrolysates ( $4 \mathrm{M} \mathrm{HCl}, 100{ }^{\circ} \mathrm{C}, 16 \mathrm{~h}$ ) of strains LMG $18084^{\mathrm{T}}$ and $\mathrm{R}-6488^{\mathrm{T}}$ were subjected to thin layer chromatography on cellulose plates using the solvent system of Rhuland et al. (1955). Meso-diaminopimelic acid was found as the diagnostic diamino acid. This has only been reported for peptidoglycan type $A 1 \gamma$ and for three variations of peptidoglycan type $A 4 \gamma$; however, these variations of peptidoglycan type $\mathrm{A} 4 \gamma$ have been found so far exclusively in members of the genera Brachybacterium, Dermabacter and Devriesia. It was clear from 16S rRNA gene sequence data that a close relationship with these three genera could be excluded, thus, it was concluded that LMG $18084^{\mathrm{T}}$ and R-6488 ${ }^{\mathrm{T}}$ showed peptidoglycan type A1 $\gamma$. The presence of meso-diaminopimelic acid is a characteristic typical for members of the genus Bacillus (Schleifer \&

Table 2. DNA-DNA relatedness values among representative strains of the dairy isolates and Bacillus thermoamylovorans LMG $18084^{\top}$

\begin{tabular}{|c|c|c|c|c|c|c|}
\hline \multirow[t]{2}{*}{ Strain } & \multirow[t]{2}{*}{$(\mathrm{GTG})_{5}$-group } & \multicolumn{5}{|c|}{ Hybridization (\%) with DNA from: } \\
\hline & & R-7499 & R-7440 & $\mathrm{R}-6488^{\mathrm{T}}$ & $\mathrm{R}-33367$ & R-6484 \\
\hline R-7440 & $\mathrm{B}$ & $97.2 \pm 12.8$ & 100 & & & \\
\hline $\mathrm{R}-6488^{\mathrm{T}}$ & $\mathrm{C}$ & $18.2 \pm 0.4$ & $20.2 \pm 0.8$ & 100 & & \\
\hline R-33367 & $\mathrm{D}$ & $21.2 \pm 1.3$ & $24.3 \pm 1.6$ & $100.0 \pm 7.7$ & 100 & \\
\hline
\end{tabular}


Table 3. Characters for distinguishing between Bacillus thermolactis sp. nov., Bacillus thermoamylovorans and other thermotolerant species of the genus Bacillus

Taxa: 1, Bacillus thermolactis sp. nov. R-6488 ${ }^{\mathrm{T}} ; 2$, Bacillus thermoamylovorans LMG $18084^{\mathrm{T}} ; 3$, Bacillus alveayuensis TM1 ${ }^{\mathrm{T}} ; 4$, Bacillus fumarioli $\mathrm{LMG}$ $17489^{\mathrm{T}}$; 5, Bacillus circulans LMG $13261^{\mathrm{T}}$; 6 , Bacillus coagulans LMG $6326^{\mathrm{T}}$; 7, Bacillus smithii LMG $12526^{\mathrm{T}}$. ST, Subterminal; T, terminal; $\mathrm{P}$, paracentral;,$+>85 \%$ positive; $\mathrm{V}$, variable ( $26-74 \%$ positive);,$- 0-15 \%$ positive; $\mathrm{W}$, weak positive reaction; $\mathrm{V}(\mathrm{W})$, variable, and weak when positive; NR, not reported. Data for Bacillus alveayuensis are from Bae et al. (2005), who obtained biochemical characters using similar methods to those used in the present work; all other data were obtained in the authors' laboratories using the same methods as those described in the present paper.

\begin{tabular}{|c|c|c|c|c|c|c|c|}
\hline Characteristic & 1 & 2 & 3 & 4 & 5 & 6 & 7 \\
\hline Motility & - & $\mathrm{V}$ & + & w & + & + & + \\
\hline Spore position & ST & ST & $\mathrm{T} / \mathrm{ST}$ & $\mathrm{P} / \mathrm{ST}$ & $\mathrm{T} / \mathrm{ST}$ & $\mathrm{ST}(\mathrm{P} / \mathrm{T})$ & ST \\
\hline Sporangia swollen & - & $\mathrm{V}$ & + & - & + & Slight & - \\
\hline Oxidase & + & + & - & - & - & $\mathrm{V}$ & $\mathrm{W}$ \\
\hline Starch hydrolysis & $\mathrm{W}$ & + & - & - & $\mathrm{W}$ & + & $\mathrm{W}$ \\
\hline Casein hydrolysis & + & - & + & - & $\mathrm{W}$ & - & - \\
\hline ONPG production & - & + & NR & - & + & + & - \\
\hline Voges-Proskauer test & - & $\mathrm{V}(\mathrm{w})$ & $\mathrm{NR}$ & + & - & $\mathrm{W}$ & $\mathrm{V}$ \\
\hline Gelatin hydrolysis & + & + & - & + & $\mathrm{V}$ & + & - \\
\hline Nitrate reduction & + & + & - & - & $\mathrm{V}$ & $\mathrm{V}$ & - \\
\hline \multicolumn{8}{|l|}{ Acid from: } \\
\hline Glycerol & - & $\mathrm{W}$ & + & $\mathrm{V}$ & + & + & + \\
\hline L-Arabinose & + & + & - & - & + & $\mathrm{V}$ & $\mathrm{V}$ \\
\hline Ribose & + & + & - & $\mathrm{V}$ & $\mathrm{V}$ & $\mathrm{V}$ & + \\
\hline D-Xylose & + & $\mathrm{V}$ & - & - & + & $\mathrm{V}$ & + \\
\hline Galactose & - & + & - & $\mathrm{v}$ & + & + & - \\
\hline D-Mannose & - & + & + & + & + & + & $\mathrm{V}$ \\
\hline myo-Inositol & - & - & - & - & + & $\mathrm{V}$ & - \\
\hline Mannitol & $\mathrm{W}$ & - & - & + & + & $\mathrm{v}$ & + \\
\hline Methyl D-glucoside & - & + & - & $\mathrm{V}$ & + & $\mathrm{V}$ & $\mathrm{V}$ \\
\hline $\mathrm{N}$-acetylglucosamine & - & + & - & $\mathrm{W}$ & + & + & - \\
\hline Amygdalin & - & + & - & - & + & $\mathrm{V}$ & - \\
\hline Arbutin & - & + & - & - & + & $\mathrm{v}$ & - \\
\hline Salicin & - & + & - & - & + & $\mathrm{v}$ & - \\
\hline Cellobiose & - & + & - & - & + & $\mathrm{v}$ & - \\
\hline Lactose & - & + & - & $\mathrm{v}$ & + & $\mathrm{V}$ & - \\
\hline Melibiose & - & + & - & $\mathrm{v}$ & + & + & - \\
\hline Melezitose & - & $\mathrm{V}$ & - & $\mathrm{v}$ & + & - & - \\
\hline Raffinose & - & $\mathrm{V}$ & - & $\mathrm{v}$ & + & $\mathrm{V}$ & - \\
\hline Starch & $\mathrm{w}$ & + & - & - & + & + & - \\
\hline Glycogen & - & + & - & - & + & - & - \\
\hline Gentiobiose & - & + & - & - & + & $\mathrm{V}$ & - \\
\hline Turanose & - & - & - & $\mathrm{v}$ & + & + & $\mathrm{V}$ \\
\hline 2-Keto-D-gluconate & - & - & + & - & $\mathrm{v}$ & - & - \\
\hline \multicolumn{8}{|l|}{ Growth at/in: } \\
\hline $30{ }^{\circ} \mathrm{C}$ & - & - & - & + & + & + & + \\
\hline $60{ }^{\circ} \mathrm{C}$ & + & - & + & - & - & + & + \\
\hline $1 \% \mathrm{NaCl}$ & - & + & + & + & + & + & + \\
\hline $2.5 \% \mathrm{NaCl}$ & - & + & + & + & + & + & - \\
\hline Anaerobic growth & + & + & - & - & + & + & + \\
\hline
\end{tabular}

Kandler, 1972). Menaquinones for type strains LMG $18084^{\mathrm{T}}$ and $\mathrm{R}-6488^{\mathrm{T}}$ were analysed as described by Groth et al. (1996). The major menaquinone was MK-7 for both strains, and strain R- $6488^{\mathrm{T}}$ also showed trace amounts of MK-8 (1\%). The type species of the genus Bacillus, i.e. Bacillus subtilis subsp. subtilis, also contains a quinone system with MK-7 predominant (Collins \& Jones, 1981), again supporting the attribution of strain $\mathrm{R}-6488^{\mathrm{T}}$ and related isolates to the genus Bacillus. Polar lipids were extracted from $100 \mathrm{mg}$ freeze-dried cell material using a chloroform/methanol $/ 0.3 \%$ aqueous $\mathrm{NaCl}$ mixture (1:2:0.8, by vol.) (modified after Bligh \& Dyer, 1959). The extraction solvent was stirred overnight and the cell debris pelleted by centrifugation. Polar lipids were recovered 
into the chloroform phase by adjusting the chloroform/ methanol/ $/ 0.3 \%$ aqueous $\mathrm{NaCl}$ mixture to a ratio of $1: 1: 0.9$ (by vol.). Polar lipids were separated by two dimensional silica gel thin layer chromatography (Machery Nagel art. no. 818135). The first direction was developed in chloroform/ methanol/water $(65: 25: 4$, by vol.), and the second in chloroform/methanol/acetic acid/water $(80: 12: 15: 4$, by vol.). Total lipid material and specific functional groups were detected using dodecamolybdophosphoric acid (total lipids), Zinzadze reagent (phosphate), ninhydrin (free amino groups), periodate-Schiff reagent (alpha-glycols), Dragendorff reagent (quaternary nitrogen) and alphanaphthol-sulphuric acid (glycolipids). Full details are given in Tindall et al. (2007). Polar lipid patterns of strains $\mathrm{R}-6488^{\mathrm{T}}$ and LMG $18084^{\mathrm{T}}$ were quite similar, complex patterns, showing diphosphatidylglycerol, phosphatidylglycerol and four to five unidentified phospholipids as the major components (Supplementary Figure S5). Phosphatidylethanolamine was detected in strain LMG $18084^{\mathrm{T}}$ but not in strain R-6488 $8^{\mathrm{T}}$. These profiles are somewhat similar to the polar lipid profile of Bacillus subtilis subsp. subtilis DSM $10^{\mathrm{T}}$ (Kämpfer et al., 2006), with diphosphatidylglycerol and phosphatidylglycerol as the major polar lipids; furthermore, phosphatidylethanolamine (as in strain LMG $18084^{\mathrm{T}}$ ) and three unidentified glycolipids (also observed in strain R$6488^{\mathrm{T}}$ ) were detected. For fatty acid methyl ester (FAME) analysis, strains were pre-cultured, then incubated for exactly $48 \mathrm{~h}$ at $52{ }^{\circ} \mathrm{C}$ on TSA (BBL, Beclon Dickinson). A loop full of well-grown cells was harvested and fatty acid methyl esters were prepared and extracted according to the standardized protocol of the Microbial Identification System (MIS; Microbial ID). All strains exhibited typical fatty acid profiles for the genus Bacillus, with a lot of branched chain components (Kaneda, 1977). Kämpfer (1994) specified fatty acid profiles of members of the genus Bacillus, containing large amounts of anteiso- $\mathrm{C}_{15: 0}(26-60 \%)$ and iso- $\mathrm{C}_{15: 0}$ $(13-30 \%)$, and low amounts of unsaturated fatty acids $(<3 \%)$. Fatty acid profiles of the dairy strains comply with this profile, and both species can be easily differentiated from one another based on different amounts of these major fatty acids, anteiso- $\mathrm{C}_{15: 0}$ and iso- $\mathrm{C}_{15: 0}$. Strains representing Bacillus thermoamylovorans had major amounts of iso- $\mathrm{C}_{15: 0}$ (mean value $23.2 \%$ ), anteiso- $\mathrm{C}_{15: 0}$ (mean value $23.4 \%$ ) and $\mathrm{C}_{16: 0}$ (mean value $17.7 \%$ ); iso- $\mathrm{C}_{16: 0}$, iso- $\mathrm{C}_{17: 0}$, anteiso- $\mathrm{C}_{17: 0}$, iso- $\mathrm{C}_{14: 0}$ and $\mathrm{C}_{14: 0}$ were present in moderate amounts (mean values of $7.9 \%, 7.1 \%, 6.7 \%, 5.0 \%$ and $4.9 \%$, respectively), and trace amounts of $\mathrm{C}_{16: 1} \omega 11 \mathrm{c}$ and $\mathrm{C}_{18: 0}$ could be observed. Strains representing Bacillus thermolactis sp. nov. had major amounts of $\mathrm{C}_{16: 0}$ (mean value $28.0 \%$ ), iso- $\mathrm{C}_{16: 0}$ (mean value $12.1 \%$ ) and iso- $\mathrm{C}_{15: 0}$ (mean value $12.0 \%) ; \quad C_{17: 0}$, anteiso- $C_{17: 0}$, anteiso- $\mathrm{C}_{15: 0}$, iso- $\mathrm{C}_{17: 0}$, $\mathrm{C}_{16: 1} \omega 11 c, \mathrm{C}_{14: 0}$ and $\mathrm{C}_{18: 0}$ were present in moderate amounts (mean values of $10.0 \%, 7.6 \%, 5.7 \%, 5.4 \%, 4.9 \%, 4.9 \%$ and $4.6 \%$, respectively), and trace amounts of iso- $\mathrm{C}_{14: 0}$ and $\mathrm{C}_{16: 1} \omega 7 c$ were also detected.

Based on cell wall composition, menaquinone analyses and major polar lipids, the dairy farm isolates could be allocated to the genus Bacillus. Furthermore, these data together with other phenotypic and genotypic data described above indicated that strains R-33520, R- $6488^{\mathrm{T}}$, R-6770， R-6491， R-7336， R-31288， R-7632， R-7165, R-28193，R-6492，R-6484，R-33367，R-26954，R-26950, R-26955, R-6486, R-26358 and R-28160 represented a novel species within the genus Bacillus, for which the name Bacillus thermolactis sp. nov. is proposed.

The four isolates, R-7499, R-6546, R-7764 and R-7440, identified as Bacillus thermoamylovorans, showed some discrepancies with the original species description (Combet-Blanc et al., 1995); therefore, an emended description of this species is given. In contrast to the original data, nitrate reduction was positive and in the API $50 \mathrm{CHB}$ gallery, positive results were obtained for acid production from melibiose and methyl D-glucoside, a weak positive result for glycerol, and negative results for gluconate and rhamnose. Furthermore, endospore formation was observed, and this was not reported in the original description of Combet-Blanc et al. (1995). In addition, fatty acid content has been determined, and peptidoglycan, quinone and polar lipid analysis has also been performed.

\section{Description of Bacillus thermolactis sp. nov.}

Bacillus thermolactis (ther.mo.lac'tis. Gr. adj. thermos hot; L. gen. n. lactis from milk; N.L. gen. n. thermolactis a thermotolerant bacterium isolated from milk).

Facultatively anaerobic, Gram-stain-positive, rod-shaped cells $(0.7-0.9 \times 4-10 \mu \mathrm{m})$ that occur either singly or in short chains of two to four cells, and in filaments. Mainly non-motile but some strains are motile by means of peritrichous flagella. After $24 \mathrm{~h}$ of incubation at $50{ }^{\circ} \mathrm{C}$ on TSA, colonies are circular and cream-coloured with irregular edges, slightly rough and matt surfaces and glossy centres, and have diameters of approximately 1-4 mm. Endospores are formed within $24 \mathrm{~h}$ of incubation at $50{ }^{\circ} \mathrm{C}$ on TSA containing $5 \mathrm{mg} \mathrm{MnSO} \mathrm{I}^{-1}$; they are ellipsoidal, lie subterminally and do not swell the cells. Growth occurs at $\mathrm{pH} 7$ but not at $\mathrm{pH} 6$ or 8 . Growth occurs between 40 and $60{ }^{\circ} \mathrm{C}$, optimally at $50{ }^{\circ} \mathrm{C}$, but does not occur at 30 or $70{ }^{\circ} \mathrm{C}$. Does not tolerate $1 \% \mathrm{NaCl}(\mathrm{w} / \mathrm{v})$ for growth. Casein is hydrolysed, starch is hydrolysed weakly, and aesculin hydrolysis is variable. Catalase and oxidase production are positive. In the API $20 \mathrm{E}$ strip, reactions for gelatin hydrolysis and nitrate reduction are positive. Arginine dihydrolase, citrate utilization, hydrogen sulphide, indole, lysine decarboxylase, ornithine decarboxylase, orthonitrophenyl- $\beta$-D-galactopyranosidase (ONPG), tryptophan deaminase, urease and the Voges-Proskauer (acetoin production) reactions are negative. Acid but no gas is produced from the following carbohydrates in the API 50 CHB gallery: trehalose (weak), D-fructose, D-glucose, D-xylose, L-arabinose, mannitol (weak), ribose, starch (weak) and sucrose (weak). Acid production is variable between strains for maltose. No acid is produced from: 2keto-D-gluconate, 5-keto-D-gluconate, adonitol, amygdalin, 
arbutin, raffinose, D-arabitol, cellobiose, D-fucose, melezitose, melibiose, turanose, D-arabinose, D-lyxose, D-mannose, D-tagatose, dulcitol, erythritol, galactose, gentiobiose, gluconate, glycerol, glycogen, inulin, L-arabitol, L-fucose, lactose, L-sorbose, L-xylose, myo-inositol, methyl Dglucoside, methyl D-mannoside, methyl xyloside, $\mathrm{N}$ acetylglucosamine, rhamnose, salicin, sorbitol or xylitol. Major fatty acids are $\mathrm{C}_{16: 0}$, iso- $\mathrm{C}_{16: 0}$ and iso- $\mathrm{C}_{15: 0}$. Major polar lipids are diphosphatidylglycerol and phosphatidylglycerol. MK-7 is the predominant menaquinone and the peptidoglycan type is $\mathrm{Al} \gamma$. The mol\% G $+\mathrm{C}$ of the DNA of the type strain is $35.0 \pm 0.2 \mathrm{~mol} \%$.

The type strain is $\mathrm{R}-6488^{\mathrm{T}} \quad\left(=\mathrm{LMG} 25569^{\mathrm{T}}=\mathrm{DSM}\right.$ $23332^{\mathrm{T}}$ ), isolated from milk and dairy farm environments. In the variable reactions listed above, the type strain is very weakly positive for acid production from maltose, and negative for aesculin hydrolysis.

\section{Emended description of Bacillus thermoamylovorans}

Bacillus thermoamylovorans (ther.mo.a.my.lo.vo' rans. Gr. adj. thermos hot; Gr. n. amulon starch; L. part. adj. vorans devouring; N.L. part. adj. thermoamylovorans utilizing starch at high temperature).

Facultatively anaerobic, Gram-positive, rod-shaped cells $(0.45-0.5 \times 3-4 \mu \mathrm{m})$ that occur either singly or in short chains of two to four cells. Usually non-motile but some strains are motile. After $24 \mathrm{~h}$ of incubation at $50{ }^{\circ} \mathrm{C}$ on TSA, colonies are circular and cream-coloured, with smooth or irregular edges, and have diameters of 0.5$4 \mathrm{~mm}$; colony surfaces range from smooth or glossy to slightly rough or matt. Endospores are formed within $24 \mathrm{~h}$ of incubation at $50{ }^{\circ} \mathrm{C}$ on TSA containing $5 \mathrm{mg} \mathrm{\textrm {MnSO } _ { 4 }}$ $\mathrm{I}^{-1}$; they are ellipsoidal, lie subterminally, and occasionally swell the cells. Growth does not occur at $\mathrm{pH} 5$ but can occur between $\mathrm{pH} 6$ and 9, with the optimum for growth being between $\mathrm{pH} 7$ and 9 . Growth occurs at $50{ }^{\circ} \mathrm{C}$, but does not occur at 40 or $60{ }^{\circ} \mathrm{C}$. Tolerates $2.5 \% \mathrm{NaCl}$ but does not tolerate $5 \% \mathrm{NaCl}(\mathrm{w} / \mathrm{v})$. Starch and aesculin are hydrolysed, but casein is not. Catalase and oxidase production are positive. In the API $20 \mathrm{E}$ strip, reactions for gelatin hydrolysis and nitrate reduction are positive. Reactions for ortho-nitrophenyl- $\beta$-D-galactopyranosidase (ONPG) production and the Voges-Proskauer (acetoin production) test are variable but the latter, when positive, is weak. Arginine dihydrolase, citrate utilization, hydrogen sulphide, indole, lysine decarboxylase, ornithine decarboxylase, tryptophan deaminase and urease reactions are negative. Acid but no gas is produced from the following carbohydrates in the API 50 CHB gallery: amygdalin, arbutin, trehalose, cellobiose, D-fructose, D-glucose, Dmannose, galactose, gentiobiose, glycerol (weak), glycogen, lactose, L-arabinose, maltose, melibiose, methyl Dglucoside, $\mathrm{N}$-acetylglucosamine, ribose, salicin, starch and sucrose. Acid production is variable between strains for raffinose, melezitose, D-xylose and methyl D-mannoside.
Acid is not produced from 2-keto-D-gluconate, 5-ketoD-gluconate, adonitol, D-arabitol, D-fucose, turanose, D-arabinose, D-lyxose, D-tagatose, dulcitol, erythritol, gluconate, inulin, L-arabitol, L-fucose, L-sorbose, L-xylose, mannitol, myo-inositol, methyl xyloside, rhamnose, sorbitol or xylitol. Major fatty acids are iso- $C_{15: 0}$, anteiso- $C_{15: 0}$ and $\mathrm{C}_{16: 0}$. Major polar lipids are diphosphatidylglycerol and phosphatidylglycerol. MK-7 is the predominant menaquinone and the peptidoglycan type is $\mathrm{Al} \gamma$. The $\mathrm{G}+\mathrm{C}$ content of the DNA of the type strain is $37.0 \pm 0.2 \mathrm{~mol} \%$. Isolated from Senegalese palm wine, milking equipment, straw and grass.

The type strain is LMG $18084^{\mathrm{T}}$. In the variable reactions listed above, the type strain has cream-coloured colonies with slightly rough, matt surfaces and irregular edges. It is positive for acid production from raffinose, melezitose, Dxylose and methyl D-mannoside although the reactions are very weak; and negative for Voges-Proskauer and ONPG.

\section{Acknowledgements}

The authors thank the Identification Service of the Deutsche Sammlung von Mikroorganismen und Zellkulturen and Dr B. J. Tindall (DSMZ, Braunschweig, Germany) for the analysis of polar lipids.

\section{References}

Andersson, A., Rönner, U. \& Granum, P. E. (1995). What problems does the food industry have with the spore-forming pathogens Bacillus cereus and Clostridium perfringens? Int J Food Microbiol 28, 145-155.

Anisimova, M. \& Gascuel, O. (2006). Approximate likelihood-ratio test for branches: a fast, accurate, and powerful alternative. Syst Biol 55, 539-552.

Ash, C., Priest, F. G. \& Collins, M. D. (1994). Molecular identification of rRNA group 3 bacilli (Ash, Farrow, Wallbanks and Collins) using a PCR probe test. Proposal for the creation of a new genus Paenibacillus. Antonie van Leeuwenhoek 64, 253-260.

Bae, S. S., Lee, J.-H. \& Kim, S.-J. (2005). Bacillus alveayuensis sp. nov., a thermophilic bacterium isolated from deep-sea sediments of the Ayu Trough. Int J Syst Evol Microbiol 55, 1211-1215.

Bligh, E. G. \& Dyer, W. J. (1959). A rapid method of total lipid extraction and purification. Can J Biochem Physiol 37, 911-917.

Collins, M. D. \& Jones, D. (1981). Distribution of isoprenoid quinone structural types in bacteria and their taxonomic implication. Microbiol Rev 45, 316-354.

Combet-Blanc, Y., Ollivier, B., Streicher, C., Patel, B. K. C., Dwivedi, P. P., Pot, B., Prensier, G. \& Garcia, J.-L. (1995). Bacillus thermoamylovorans sp. nov., a moderately thermophilic and amylolytic bacterium. Int J Syst Bacteriol 45, 9-16.

Coorevits, A., De Jonghe, V., Vandroemme, J., Reekmans, R., Heyrman, J., Messens, W., De Vos, P. \& Heyndrickx, M. (2008). Comparative analysis of the diversity of aerobic spore-forming bacteria in raw milk from organic and conventional dairy farms. Syst Appl Microbiol 31, 126-140.

Crielly, E. M., Logan, N. A. \& Anderton, A. (1994). Studies on the Bacillus flora of milk and milk products. J Appl Bacteriol 77, 256-263. 
Ezaki, T., Hashimoto, Y. \& Yabuuchi, E. (1989). Fluorometric deoxyribonucleic acid-deoxyribonucleic acid hybridization in microdilution wells as an alternative to membrane filter hybridization in which radioisotopes are used to determine genetic relatedness among bacterial strains. Int J Syst Bacteriol 39, 224-229.

Fortina, M. G., Pukall, R., Schumann, P., Mora, D., Parini, C., Manachini, P. L. \& Stackebrandt, E. (2001). Ureibacillus gen. nov., a new genus to accommodate Bacillus thermosphaericus (Andersson et al. 1995), emendation of Ureibacillus thermosphaericus and description of Ureibacillus terrenus sp. nov. Int J Syst Evol Microbiol 51, 447-455.

Groth, I., Schumann, P., Weiss, N., Martin, K. \& Rainey, F. A. (1996). Agrococcus jenensis gen. nov., sp. nov., a new genus of actinomycetes with diaminobutyric acid in the cell wall. Int J Syst Bacteriol 46, 234-239.

Guindon, S. \& Gascuel, O. (2003). A simple, fast, and accurate algorithm to estimate large phylogenies by maximum likelihood. Syst Biol 52, 696-704.

Heyndrickx, M., Lebbe, L., Kersters, K., De Vos, P., Forsyth, G. \& Logan, N. A. (1998). Virgibacillus: a new genus to accommodate Bacillus pantothenticus (Proom and Knight 1950). Emended description of Virgibacillus pantothenticus. Int J Syst Bacteriol 48, 99-106.

Heyrman, J. \& Swings, J. (2001). 16S rDNA sequence analysis of bacterial isolates from biodeteriorated mural paintings in the Servilia tomb (necropolis of Carmona, Seville, Spain). Syst Appl Microbiol 24, 417-422.

Heyrman, J., Vanparys, B., Logan, N. A., Balcaen, A., Rodríguez-Díaz, M., Felske, A. \& De Vos, P. (2004). Bacillus novalis sp. nov., Bacillus vireti sp. nov., Bacillus soli sp. nov., Bacillus bataviensis sp. nov. and Bacillus drentensis sp. nov., from the Drentse A grasslands. Int J Syst Evol Microbiol 54, 47-57.

Heyrman, J., Verbeeren, J., Schumann, P., Swings, J. \& De Vos, P. (2005). Six novel Arthrobacter species isolated from deteriorated mural paintings. Int J Syst Evol Microbiol 55, 1457-1464.

Kämpfer, P. (1994). Limits and possibilities of total fatty acid analysis for classification and identification of Bacillus species. Syst Appl Microbiol 17, 86-98.

Kämpfer, P., Rosselló-Mora, R., Falsen, E., Busse, H.-J. \& Tindall, B. J. (2006). Cohnella thermotolerans gen. nov., sp. nov., and classification of 'Paenibacillus hongkongensis' as Cohnella hongkongensis sp. nov. Int J Syst Evol Microbiol 56, 781-786.

Kaneda, T. (1977). Fatty acids of the genus Bacillus: an example of branched-chain preference. Bacteriol Rev 41, 391-418.

Logan, N. A. \& De Vos, P. (2009). Genus Bacillus Cohn 1872. In Bergey's Manual of Systematic Bacteriology, 2nd edn, vol. 3, pp. 21128. Edited by P. De Vos, G. Garrity, D. Jones, N. R. Krieg, W. Ludwig, F. A. Rainey, K.-H. Schleifer \& W. B. Whitman. New York: Springer.

Logan, N. A., Lebbe, L., Hoste, B., Goris, J., Forsyth, G., Heyndrickx, M., Murray, B. L., Syme, N., Wynn-Williams, D. D. \& De Vos, P. (2000). Aerobic endospore-forming bacteria from geothermal environments in northern Victoria Land, Antarctica, and Candlemas Island, South Sandwich archipelago, with the proposal of Bacillus fumarioli sp. nov. Int J Syst Evol Microbiol 50, 1741-1753.

Logan, N. A., Berge, O., Bishop, A. H., Busse, H.-J., De Vos, P., Fritze, D., Heyndrickx, M., Kämpfer, P., Rabinovitch, L. \& other authors (2009).
Proposed minimal standards for describing new taxa of aerobic, endospore-forming bacteria. Int J Syst Evol Microbiol 59, 2114-2121.

Meer, R. R., Baker, J., Bodyfelt, F. W. \& Griffiths, M. W. (1991). Psychrotrophic Bacillus spp. in fluid milk products: a review. J Food Prot 54, 969-979.

Mesbah, M., Premachandran, U. \& Whitman, W. (1989). Precise measurement of the $\mathrm{G}+\mathrm{C}$ content of deoxyribonucleic acid by high performance liquid chromatography. Int J Syst Bacteriol 39, 159-167.

Nazina, T. N., Tourova, T. P., Poltaraus, A. B., Novikova, E. V., Grigoryan, A. A., Ivanova, A. E., Lysenko, A. M., Petrunyaka, V. V., Osipov, G. A. \& other authors (2001). Taxonomic study of aerobic thermophilic bacilli: descriptions of Geobacillus subterraneus gen. nov., sp. nov. and Geobacillus uzenensis sp. nov. from petroleum reservoirs and transfer of Bacillus stearothermophilus, Bacillus thermocatenulatus, Bacillus thermoleovorans, Bacillus kaustophilus, Bacillus thermoglucosidasius and Bacillus thermodenitrificans to Geobacillus as the new combinations G. stearothermophilus, $G$. thermocatenulatus, G. thermoleovorans, G. kaustophilus, G. thermoglucosidasius and G. thermodenitrificans. Int J Syst Evol Microbiol 51, 433-446.

Pettersson, B., Lembke, F., Hammer, P., Stackebrandt, E. \& Priest, F. G. (1996). Bacillus sporothermodurans, a new species producing highly heat-resistant endospores. Int J Syst Bacteriol 46, 759-764.

Posada, D. (2008). jModelTest: phylogenetic model averaging. Mol Biol Evol 25, 1253-1256.

Rhuland, L. E., Work, E., Denman, R. F. \& Hoare, D. S. (1955). The behavior of the isomers of $\alpha, \varepsilon$-diaminopimelic acid on paper chromatograms. J Am Chem Soc 77, 4844-4846.

Scheldeman, P., Pil, A., Herman, L., De Vos, P. \& Heyndrickx, M. (2005). Incidence and diversity of potentially highly heat-resistant spores isolated at dairy farms. Appl Environ Microbiol 71, 1480-1494.

Schleifer, K. H. \& Kandler, O. (1972). Peptidoglycan types of bacterial cell walls and their taxonomic implications. Bacteriol Rev 36, 407-477.

Shida, O., Takagi, H., Kadowaki, K. \& Komagata, K. (1996). Proposal for two new genera, Brevibacillus gen. nov. and Aneurinibacillus gen. nov. Int J Syst Bacteriol 46, 939-946.

Stackebrandt, E. \& Ebers, J. (2006). Taxonomic parameters revisited: tarnished gold standards. Microbiol Today 33, 152-155.

Tamura, K., Dudley, J., Nei, M. \& Kumar, S. (2007). MEGA4: molecular evolutionary genetics analysis (MEGA) software version 4.0. Mol Biol Evol 24, 1596-1599.

Thompson, J. D., Gibson, T. J., Plewniak, F., Jeanmougin, F. \& Higgins, D. G. (1997). The CLUSTAL_X windows interface: flexible strategies for multiple sequence alignment aided by quality analysis tools. Nucleic Acids Res 25, 4876-4882.

Tindall, B. J., Sikorski, J., Smibert, R. M. \& Krieg, N. R. (2007). Phenotypic characterization and the principles of comparative systematics. In Methods for General and Molecular Microbiology, 3rd edn, pp. 330-393. Edited by C. A. Reddy, T. J. Beveridge, J. A. Breznak, G. Marzluf, T. M. Schmidt \& L. R. Snyder. Washington, DC: American Society for Microbiology.

Willems, A., Doignon-Bourcier, F., Goris, J., Coopman, R., de Lajudie, P., De Vos, P. \& Gillis, M. (2001). DNA-DNA hybridization study of Bradyrhizobium strains. Int J Syst Evol Microbiol 51, 1315-1322. 